Jurnal Laut Khatulistiwa, Vol. 3, No. 1 (Febuari, 2020), Hal. 1-9.

ISSN : 2614-6142 (Printed), 2614-8005 (Online)

http://jurnal.untan.ac.id/index.php/lk

JURNAL LAUT

KHATULISTIWA

\title{
Kepadatan dan Pola Distribusi Polymesoda erosa di Ekosistem Mangrove Desa Peniti, Kabupaten Mempawah Kalimantan Barat
}

\section{Density and Distribution Pattern of Polymesoda erosa in Mangrove Ecosystem, Peniti Village Mempawah Regency, West Kalimantan}

\author{
Deni $^{1}$, Warsidah ${ }^{*}$, Syarif Irwan Nurdiansyah ${ }^{1}$ \\ ${ }^{1}$ Laboratorium Ilmu Kelautan, FMIPA Universitas Tanjungpura, Pontianak, Indonesia \\ *E-mail : warsidah@fmipa.untan.ac.id
}

Received : 9 October 2019; Accepted : 19 Desember 2019

Published: 27 Febuari 2020 (c) Author(s) 2020. This article is open access

\begin{abstract}
Polymesoda erosa is a species that lives in mud in estuarine areas, in brackish water mangrove forests and large rivers. The Peniti Village of Mempawah Regency is one of the main hunting grounds of Polymesoda erosa by the community both for self-consumption and for sale. This can affect the population of Polymesoda erosa in the region. The purpose of this study was to determine the density and distribution patterns of Polymesoda erosa using the Systematic Sampling method by dividing the study area into 4 (four) stations. The results showed that Polymesoda erosa totaled 217 individuals, consisting of 43 individuals at the station I, 93 individuals at station II, 41 individuals at station III, and 40 individuals at station IV. The highest polymesoda era at station II (93 individuals), while the lowest at station IV (40 individuals). The highest average density of Polymesoda erosa is found at station II, which is 0.93 ind $/ \mathrm{m}^{2}$, while the lowest average density is at station IV which is $0.4 \mathrm{ind} / \mathrm{m}^{2}$. The distribution of Polymesoda erosa is based on the Morisita degree standard value of 0.023, which shows the distribution of Polymesoda erosa is clustered.
\end{abstract}

Keywords : Polymesoda erosa, density, distribution, systematic sampling

\begin{abstract}
Abstrak
Jenis Polymesoda erosa merupakan salah satu spesies yang hidup di dalam lumpur pada daerah estuari, di hutan mangrove air payau dan di sungai-sungai besar. Desa Peniti Kabupaten Mempawah merupakan salah satu tempat buruan utama Polymesoda erosa oleh masyarakat baik untuk dikonsumsi sendiri maupun untuk diperjualbelikan. Hal ini dapat berpengaruh terhadap jumlah populasi Polymesoda erosa di wilayah tersebut. Tujuan dari penelitian ini adalah untuk mengetahui kepadatan dan pola distribusi Polymesoda erosa menggunakan metode Sistematik Sampling dengan membagi wilayah penelitian menjadi 4 (empat) stasiun. Hasil penelitian menunjukkan Polymesoda erosa yang diperoleh berjumlah 217 individu, yang terdiri atas 43 individu pada stasiun I, 93 individu pada stasiun II, 41 individu pada stasiun III, dan 40 individu pada stasiun IV. Polymesoda erosa tertinggi pada stasiun II (93 individu), sedangkan terendah pada stasiun IV (40 individu). Kepadatan rata-rata tertinggi Polymesoda erosa terdapat pada stasiun II yaitu mencapai $0,93 \mathrm{ind} / \mathrm{m}^{2}$, sedangkan kepadatan rata-rata terendah terdapat pada stasiun IV yang senilai 0,4 ind $/ \mathrm{m}^{2}$. Distribusi Polymesoda erosa berdasarkan nilai standar derajat Morisita yaitu 0,023, yang menunjukan sebaran Polymesoda erosa bersifat mengelompok.
\end{abstract}

Kata kunci : Polymesoda erosa, kepadatan, distribusi, sistematik sampling

\section{Pendahuluan}

Hutan mangrove merupakan salah satu formasi hutan yang berpengaruh terhadap biota dan fauna serta sebagai penyambung ekosistem daratan dan ekosistem lautan. Hutan mangrove terdapat di pantai yang rendah dan tenang, berlumpur atau sedikit berpasir yang mendapat pengaruh pasang surut air laut (Noor et al., 2006). Ekosistem 
Jurnal Laut Khatulistiwa, Vol. 3, No. 1 (Febuari, 2020), Hal. 1-9.

mangrove sering dijumpai di sepanjang estuari daerah tropis dan subtropis. Interaksi antara ekosistem mangrove, lamun dan terumbu karang dengan lingkungannya mampu menciptakan suatu kondisi perairan yang cocok untuk berlangsungnya proses biologi dan menguntungkan berbagai macam organisme akuatik. Daerah mangrove juga memegang kunci dalam perputaran nutrisi sehingga eksistensinya dapat berperan menopang dan memberikan tempat hidup bagi biota laut (Pramudji, 2007).

Mangrove yang terdapat di muara sungai Peniti memiliki arti penting bagi kehidupan masyarakat sekitarnya karena memiliki kelimpahan biota yang sangat beragam, seperti kepah bakau (Polymesoda sp.) dan kepiting bakau (Scylla serrata). Mangrove muara Sungai Peniti juga berfungsi sebagai pelindung desa dari gelombang laut dan sebagai tempat hidup bagi spesies hewan seperti monyet ekor panjang (Macaca multifasciata) dan beberapa spesies burung (Prisma, 2011).

Menurut Morton (1976) secara morfologi kerang kepah mempunyai bentuk cangkang seperti piring atau cawan yang terdiri dari dua katub yang bilateral simetris, pipih pada bagian pinggirnya dan cembung pada bagian tengah cangkang, bentuk cangkang yang equivalve atau berbentuk segitiga yang membulat, tebal, flexure jelas mulai dari umbo sampai dengan tepi posterior. Franklin et al., 1980; Mason, 1983, menambahkan, kedua katub dihubungkan oleh hinge ligamen dan dengan bantuan otot aduktor berfungsi untuk membuka atau menutup cangkang.

Ciri khas Polymesoda erosa yaitu memiliki dua cangkang dikedua sisinya dengan engsel di bagian dorsalnya. Cangkang ini memiliki fungsi utama sebagai pelindung tubuh dari serangan predator, lingkungan dan mengatur aliran air yang masuk ke dalam insang. Jaringan tubuh yang terlindungi oleh cangkang memiliki organ yang disebut mantel. Mantel ini melekat pada bagian dalam cangkang dengan bantuan otot yang ditandai dengan bekas lengkungan yang disebut pallial line. Bentuk tubuh dari kerang ini tergolong simetris bilateral (Romimohtarto dan Juwana, 2009).

Bivalvia memiliki alat pencernaan sempurna mulai dari mulutnya yang mempunyai lidah perut (Radula) sampai dengan anus terbuka di daerah rongga mantel. Memiliki kelenjar pencernaan yang sudah berkembang. Peredaran darah terbuka terjadi pada semua kelas Bivalvia kecuali kelas Cephalopoda. Perrnafasan dilakukan dengan menggunakan insang, mantel atau oleh bagian epidermis. Alat ekskresi berupa ginjal dan sistem saraf terdiri dari atas tiga pasang ganglion yaitu cerebral, ganglion visceral dan ganglion pedal yang ketiganya dihubungkan oleh tali - tali saraf longi tudinal. Alat reproduksi umumnya terpisah atau bersatu dan pembuahan internal atau eksternal (Soegianto dan Supriyanto, 2008).

Manfaat Polymesoda erosa adalah memiliki nilai ekonomis dan gizi yang relatif tinggi. Harga jual Polymesoda erosa iniberkisar antara Rp 5.500 hingga Rp 6.000/kg dan nilai jualnya menjadi lebih tinggi apabila sudah menjalani proses pengolahan (Supriyantini et al., 2007). Nilai gizi kelompok kerang memiliki kandungan protein sebesar 7,06 \% hingga $16,87 \%$, lemak sebesar $0,4 \%$ hingga 2,47 \%, karbohidrat sebesar 2,36 \% hingga 4,95\% serta memberikan energi sebesar 69 hingga 88 kkal/100 g daging (Amin, 2009).

Bivalvia jenis Polymesoda erosa merupakan spesies kepah yang hidup di ekosistem mangrove. Polymesoda erosa ini banyak dijumpai di hutan mangrove Indo-Pasifik Barat mulai dari India, Malaysia, Indonesia, Thailand, Vietnam, Burma, Philipina (Morton, 1984). Peniti merupakan salah satu tempat yang melakukan pengambilan Polymesoda erosa. Polymesoda erosa di ekosistem mangrove Desa Peniti selain diambil untuk dikonsumsi sendiri dan diperjual belikan. Hampir setiap hari dapat ditemui para pedagang menjual Polymesoda erosa di tepi jalan raya Desa Peniti.

Hasil penelitian yang dilakukan oleh Hasibuan et al. (2018) kepah Polymesoda erosa melimpah di dekat muara. Hal ini disebabkan tingginya kelimpahan bahan organik pada substrat maupun didukung nilai faktor fisika kimia. Subsrat juga sangat berpengaruh pada kepadatan Polymesoda erosa. Pengambilan Polymesoda erosa yang dilakukan masyarakat tanpa memilih ukuran dapat mempengaruhi kepadatan populasi kepah. Apabila Polymesoda erosa terus diambil maka Polymesoda erosa akan mengalami resiko kepunahan di habitatnya. Hal tersebut dapat dengan pengelolaan berkelanjutan yang sangat 
Jurnal Laut Khatulistiwa, Vol. 3, No. 1 (Febuari, 2020), Hal. 1-9.

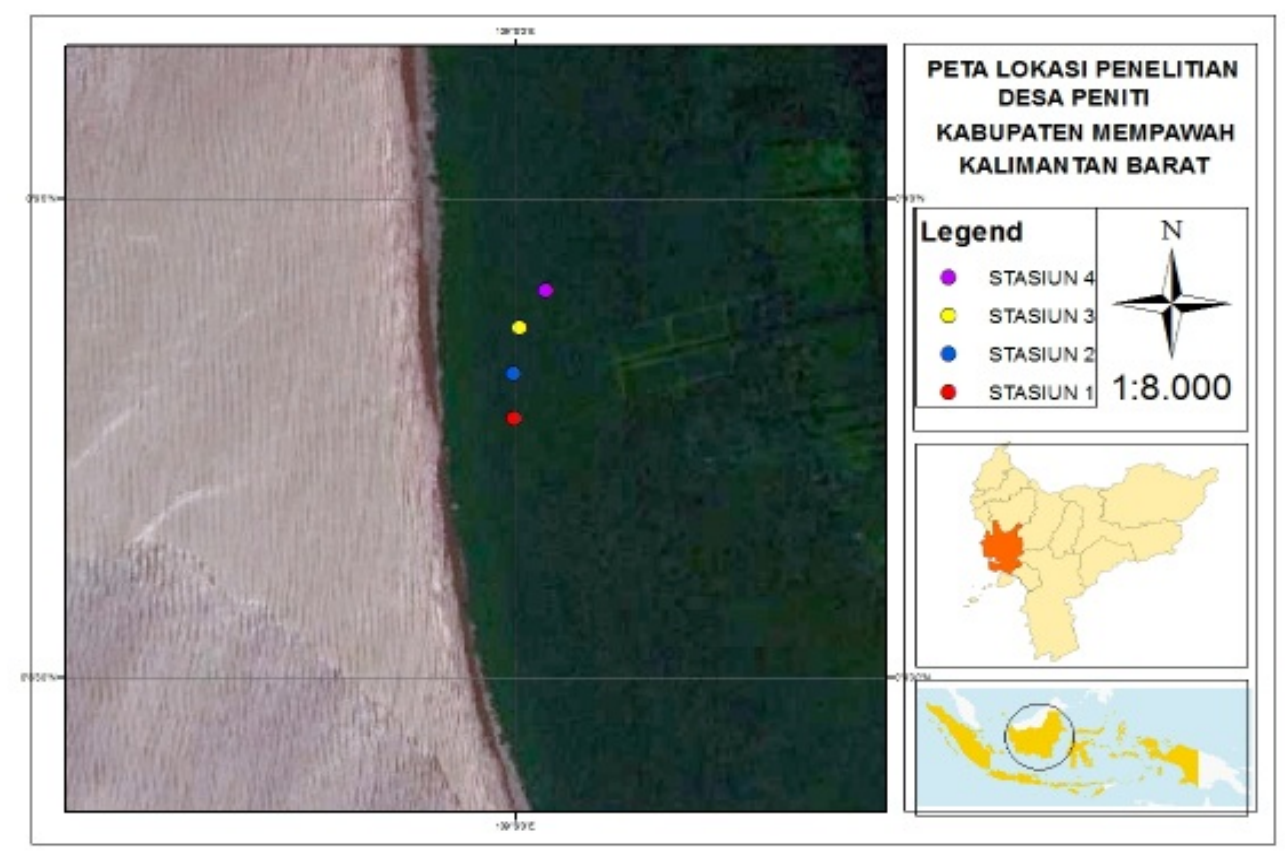

Gambar 1. Peta lokasi penelitian ekosistem mangrove Desa Peniti

memerlukan informasi termasuk kepadatan dan pola distribusi Polymesoda erosa. Data tersebut tentunya sangat diperlukan oleh pemerintah dan masyarakat untuk pengolahan kepah berkelanjutan. Oleh karena itu perlunya penelitian tentang kepadatan populasi dan pola distribusi Polymesoda erosa di Ekosistem Mangrove Desa Peniti, Kabupaten Mempawah, Kalimantan Barat.

\section{Metode}

\subsection{Waktu dan Tempat Penelitian}

Penelitian ini dilakukan dari tanggal 26 Januari (1 hari) di ekosistem mangrove Desa Peniti Kabupaten Mempawah Kalimantan Barat dan 9 - 15 Februari 2019 di Laboratorium Mekanika Tanah Fakultas Teknik Universitas Tanjungpura Pontianak, dengan metode Sistematik sampling. Pengambilan sampel menggunakan metode Belt transek. Transek dibuat pada setiap stasiun sepanjang $25 \mathrm{~m}$, dengan arah tegak lurus terhadap garis pantai. Setiap transek terdapat 5 plot, berukuran $5 \times 5 \mathrm{~m}$. Pengambilan sampel dilakukan pada setiap plot saat surut terendah. Lokasi ditemukannya Polymesoda erosa akan ditandai pada papan bergaris. Selama pengambilan sampel juga dilakukan pengukuran suhu air, $\mathrm{pH}$ air, $\mathrm{pH}$ tanah, salinitas dan pengambilan substrat.

\subsection{Analisis Data}

Kepadatan Polymesoda erosa dihitung menggunakan rumus berikut (Michael, 1994).

$K=\frac{n}{A}$

Keterangan:

$\mathrm{K}:$ Kepadatan (Ind/ $\mathrm{m}^{2}$ )

$\mathrm{n}$ : Jumlah individu suatu spesies (Ind)

A : Luas $\left(\mathrm{m}^{2}\right)$

Pola distribusi Polymesoda erosa dihitung menggunakan Indeks Morisita (Id) dengan rumus sebagai berikut (Jongjitvimol et al., 2005).

$$
I d=n \frac{\left(\sum x_{i}^{2}-\sum N_{i}\right)}{\left(\sum x_{i}\right)^{2}-\sum x_{i}}
$$

(5)

Keterangan:

Id : Indeks Morisita

$\mathrm{N}$ : jumlah seluruh individu dalam total $\mathrm{n}$

$n$ : jumlah seluruh plot pengambilan sampel

$\mathrm{x}$ : jumlah individu pada setiap kelompok

Nilai Indeks penyebaran Morisita diuji dengan menghitung standar derajat Morisita yang 
Jurnal Laut Khatulistiwa, Vol. 3, No. 1 (Febuari, 2020), Hal. 1-9.

diperoleh melalui penentuan nilai $M_{u}$ dan $M_{c}$ sebagai berikut :

$$
\begin{aligned}
& M_{u}=\frac{X^{2}(0.975-n)+\sum x_{i}}{\left(\sum x_{i}-1\right)} \\
& M_{c}=\frac{X^{2}(0.025-n)+\sum x_{i}}{\left(\sum x_{i}-1\right)}
\end{aligned}
$$

Keterangan :

$M_{u}$ : Indeks Morisita untuk pola sebaran seragam

$M_{c}$ : Indeks Morisita untuk pola sebaran mengelompok

Standar derajat Morisita dihitung menggunakan rumus berikut :

$$
I p=0.5+0.5\left(\frac{I d-M_{c}}{n-M_{c}}\right) ;
$$

jika $I d \geq M_{c}>1$

$$
\text { (5) }
$$

$$
\begin{aligned}
& I p=0.5\left(\frac{I d-1}{M_{c}-1}\right) ; \text { jika } M_{c}>I d \geq 1 \\
& I p=-0.5\left(\frac{I d-1}{M_{u}-1}\right) ; \text { jika } 1>I d>M_{u} \\
& I p=-0.5+0.5\left(\frac{I d-M_{u}}{M_{u}}\right) ;
\end{aligned}
$$

jika $1>M_{u}>I d$

Rumus Ip yang didapat dijelaskan dengan nilai: $I p<0$ : Penyebaran individu bersifat merata $I p=0 \quad$ : Penyebaran individu bersifat acak
Ip $>0$ : Penyebaran individu bersifat mengelompok

\section{Hasil dan Pembahasan}

Sampel Polymesoda erosa yang diperoleh di ekosistem mangrove Desa Peniti Kabupaten Mempawah berjumlah 217 individu, yang terdiri atas 43 individu pada stasiun I, 93 individu pada stasiun II, 41 individu pada stasiun III, dan 40 individu pada stasiun IV. Polymesoda erosa tertinggi pada stasiun II (93individu), sedangkan terendah pada stasiun IV (40 individu).

\subsection{Pola Disktribusi Polymesoda erosa di Ekosistem Mangrove Desa Peniti}

Berdasarkan grafik di atas kepadatan ratarata tertinggi Polymesoda erosa terdapat pada stasiun II yaitu mencapai $0,93 \mathrm{ind} / \mathrm{m}^{2}$, sedangkan kepadatan rata-rata terendah terdapat pada stasiun IV yang senilai 0,4 ind $/ \mathrm{m}^{2}$. Kepadatan Polymesoda erosa di stasiun II lebih tinggi dibandingkan stasiun lainnya, diasumsikan bahwa Polymesoda erosa menyukai habitat yang memiliki subsrat berpasir dan tidak menyukai habitat dengan substrat lempung, hal ini sesuai dengan nilai analisis regresi parameter yang paling berpengaruh terhadap kepadatan Polymesoda erosa adalah substrat berpasir. Sou (2010) dalam Marwanto (2018) yaitu di daerah pasang surut yang datar dan berpasir, biasanya banyak terdapat di dekat muara-muara sungai

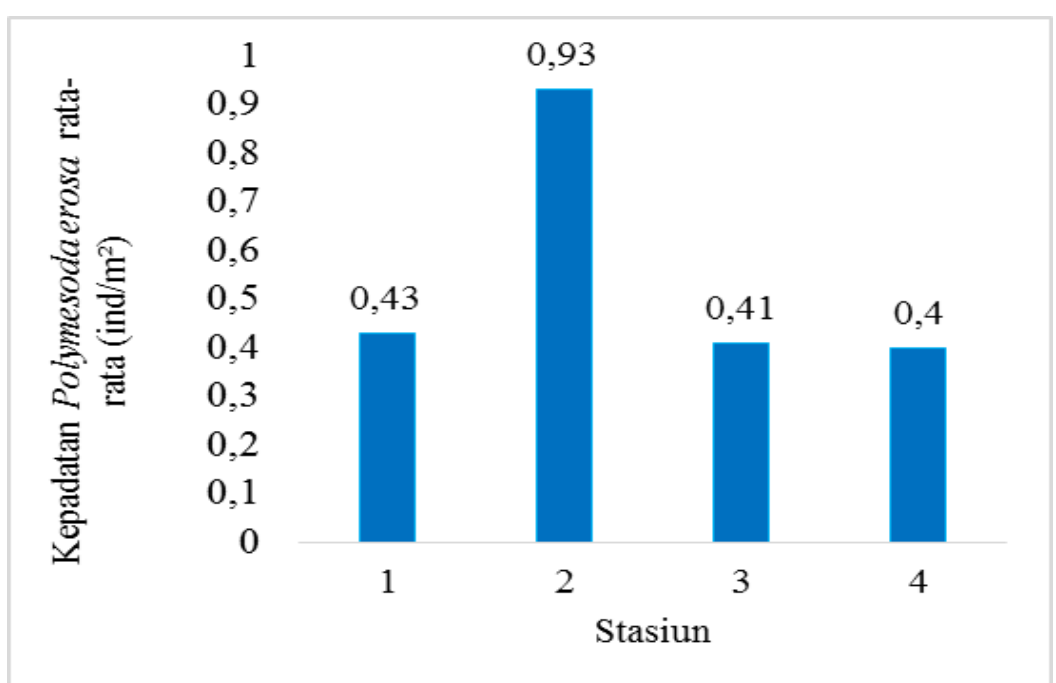

Gambar 2. Kepadatan rata-rata Polymesoda erosa di ekosistem mangrove Desa Peniti (sumber : data primer) 
Jurnal Laut Khatulistiwa, Vol. 3, No. 1 (Febuari, 2020), Hal. 1-9.

berukuran kecil. Menurut Kresnasari (2010) berbagai faktor lingkungan sangat mempengaruhi turunnya produktivitas biota perairan.

Faktor lingkungan yang berpengaruh turunnya produktivitas apabila kondisi lingkungan pada daerah tersebut tidak optimal bagi kehidupan kepah. Amin (2009) juga menyatakan bahwa kepadatan Polymesoda erosa dipengaruhi oleh perbedaan karakteristik masing-masing stasiun pengambilan sampel. Setiap stasiun memiliki faktor lingkungan yang berbeda, jika pada stasiun tersebut memiliki faktor lingkungan yang baik, maka kepadatan kepah juga akan banyak. Hal ini sesuai dengan kondisi lingkungan yang terdapat di lapangan, bahwa fraksi lanau dan pasirpada stasiun II lebih besar dibandingkan dengan stasiun lainnya.

Berdasarkan Tabel $1 \mathrm{di}$ atas dapat dilihat bahwa nilai standar derajat Morisita yaitu 0,023, yang menunjukan distribusi Polymesoda erosa bersifat mengelompok (Tabel 1). Hal ini sesuai dengan pernyataan Listyaningsih. (2013) Polymesoda erosa memiliki pola mengelompok, ini merupakan bentuk penyebaran paling umum yang terjadi di alam. Pola mengelompok terjadi sebagai akibat dari adanya perbedaan respon terhadap perbedaan habitat secara lokal. Menurut Kresnasari (2010) pola distribusi dari Polymesoda erosa berkaitan dengan tingkah laku, strategi reproduksi, kesediaan pakan dan kondisi lingkungan.

Menurut Yunus et al. (2015) tentang distribusi bivalvia di muara Sungai Kawal
Kepulauan Riau yaitu semua bivalvia yang ditemukan sebanyak 5 jenis memiliki pola distribusi mengelompok. Menurut Rudi (1999) bahwa pola penyebaran mengelompok menandakan bahwa hewan tersebut hanya dapat hidup pada habitat tertentu saja dengan kondisi lingkungan yang cocok. Hal ini merupakan bentuk penyebaran paling umum yang terjadi di alam. Kelompok individu yang hidup secara berkelompok memiliki kemampuan mobilitas yang rendah sehingga sukar untuk menyebar dan berpindah-pindah. Jenis-jenis yang mempunyai pola penyebaran mengelompok menunjukkan bahwa kehidupannya membutuhkan habitat yang khas, sehingga pola penyebaran jenis-jenis ini sempit dan terbatas.

Kelompok individu yang hidup secara berkelompok memiliki kemampuan mobilitas yang rendah sehingga sukar untuk menyebar dan berpindah-pindah. Jenis-jenis yang mempunyai pola penyebaran mengelompok menunjukkan bahwa kehidupannya membutuhkan habitat yang khas, sehingga pola penyebaran jenis-jenis ini sempit dan terbatas.

Odum (1994) menyatakan bahwa pola penyebaran biota di alam umumnya terjadi secara mengelompok dan jarang sekali terjadi acak. Sifat individu yang cenderung mengelompok tersebut sebagai akibat respon terhadap perubahan cuaca dan musim, perubahan habitat dan proses reproduktif. Pola penyebaran mengelompok sangat tidak menguntungkan karena dapat meningkatkan persaingan antar individu dalam mendapatkan

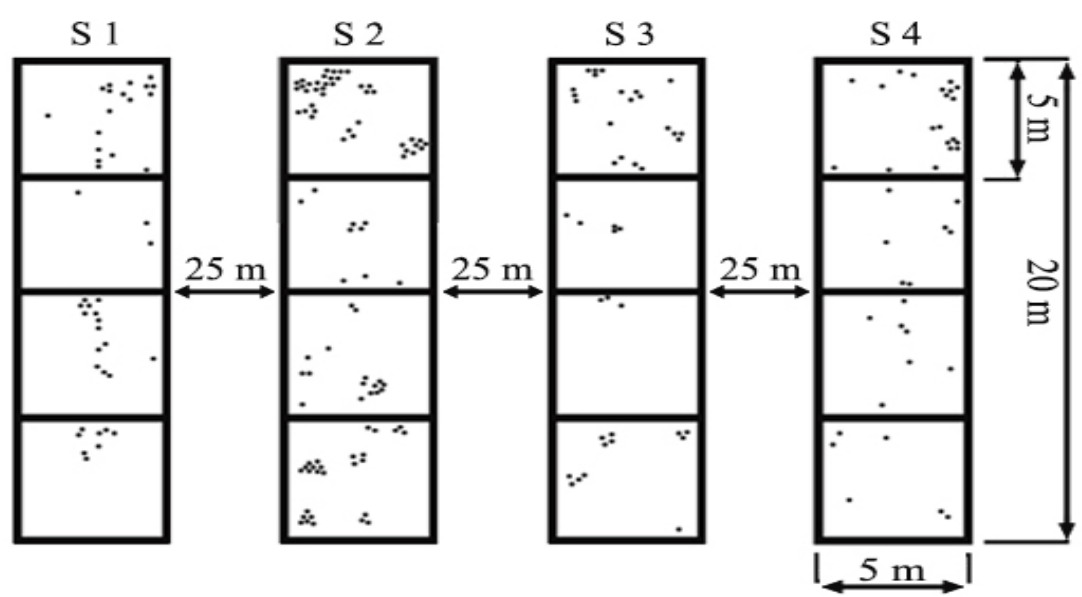

Gambar 3. Pola distribusi Polymesoda erosa yang ditemukan di ekosistem mangrove Desa Peniti 
Jurnal Laut Khatulistiwa, Vol. 3, No. 1 (Febuari, 2020), Hal. 1-9.

Tabel 1. Pola distribusi Polymesoda erosa di ekosistem mangrove Desa Peniti

\begin{tabular}{ccccc}
\hline Jenis & Id & Mc & Ip )* & Penyebaran \\
\hline Polymesoda erosa & 1,459 & 1,109 & 0,023 & Mengelompok \\
\hline
\end{tabular}

Keterangan : )* : Penyebaran individu bersifat kelompok (Ip<0 : Penyebaran individu besifat merata; Ip=0 : Penyebaran individu bersifat acak; Ip>0 : Penyebaran individu bersifat mengelompok) (Id : Indeks Morisita; Mc : Indeks Morisita untuk sebaran mengelompok; Ip : Standar derajat Morisita)

makanan dan ruang sebagai tempat hidupnya. Menurut Manzi dan Castagna (1989) faktor pemangsaan, penyebaran larva, pasang surut dan pengambilan Polymesoda erosa juga dapat mempengaruhi nilai kepadatan. Saat penyebaran, larva mencari habitat yang cocok, berkembang menjadi Bivalvia muda, menetap hingga dewasa dan matang gonad.

\subsection{Faktor-Faktor Lingkungan Ekosistem Mangrove Desa Peniti}

Faktor lingkungan yang mempengaruhi kepadatan dan pola distribusi (Polymesoda erosa) di ekosistemnya yaitu suhu air, $\mathrm{pH}$ air, salinitas, dan $\mathrm{pH}$ tanah. Kepadatan Polymesoda erosa antara stasiun menunjukkan nilai yang tidak signifikan. Uji Kruskal-Wallis yang telah dilakukan menunjukkan Hasil pengambilan suhu yang telah dilakukan pada 4 stasiun di ekosistem mangrove Desa Peniti Kabupaten Mempawah berkisar antara $26^{\circ} \mathrm{C}-28,5$ kepadatan Polymesoda erosa antar stasiun tidak berbeda nyata (Asympg. Sig. 0,280 > 0,05). Hasil pengukuran faktor lingkungan dapat dilihat pada tabel $2 .^{\circ} \mathrm{C}$ (Tabel 2). Suhu tersebut sesuai dengan suhu optimum untuk pertumbuhan Polymesoda erosa. Menurut pernyataan yang disampaikan oleh Kastoro (1988) dan Farhan (1998) dalam Melinda et al. (2015), suhu toleransi bagi kehidupan Bivalvia berkisar antara $20^{\circ} \mathrm{C}-35^{\circ} \mathrm{C}$. Hal ini juga diperkuat oleh Farhan (1998) dalam Melinda et al. (2015) bahwa suhu yang optimum bagi kehidupan kepah adalah $20^{\circ} \mathrm{C}-3^{\circ} \mathrm{C}$, pada suhu $30^{\circ} \mathrm{C}$ dapat merangsang kepah betina untuk bertelur.

Wicaksono (2002) dalam Akbar et al. (2014) menyatakan bahwa pertumbuhan organisme yang merupakan proses metabolisme dipengaruhi oleh faktor luar yang salah satunya adalah suhu. Proses metabolisme akan berjalan secara normal jika suhu lingkungan berada pada suhu yang optimum. Nilai derajat keasaman $(\mathrm{pH})$ perairan pada penelitian ini berkisar antara 8,2 - 8,4 (Tabel 2). Derajat keasaman $(\mathrm{pH})$ tertinggi terdapat pada stasiun III dan IV yaitu 8,4 sedangkan nilai $\mathrm{pH}$ terendah terdapat pada stasiun I. Nilai pH yang didapatkan, masih sesuai bagi kehidupan kepah. Menurut Simanjuntak (2009), pada umumnya nilai $\mathrm{pH}$ dalam suatu perairan berkisar antara 4-9. Suwondo (2012) menambahkan bahwa kisaran $\mathrm{pH}$ air yang mendukung kehidupan bivalvia adalah berkisar 6-9. Junaidi et al. (2010) menyatakan nilai $\mathrm{pH}<5$ atau $\mathrm{pH}>9$ tidak sesuai bagi kehidupan makrozoobentos. Nilai pH substrat yang didapat pada penelitian ini berkisar antara 5,3-6,3. Nilai pH tertinggi terdapat pada stasiun II dan IV yaitu 6,3 sedangkan nilai $\mathrm{pH}$ terendah terdapat pada stasiun III yaitu 5,3 . Nilai $\mathrm{pH}$ yang didapat pada penelitian ini masih bisa dikatakan sesuai bagi kehidupan kepah.

Menurut penelitian Hasibuan et al. (2018) $\mathrm{pH}$ substrat yang sesuai bagi kehidupan Bivalvia berkisar 6 - 9, sedangkan menurut Kresnasari (2010), pH untuk habitat Polymesoda erosa yaitu berkisar antara 6,16 ,9. Salinitas yang diukur pada penelitian ini berkisar antara 27,3 - 28 ppt, hal tersebut masih dikatakan sesuai bagi kehidupan kepah. Kharisma et al. (2012) menyatakan bahwa, salinitas yang baik bagi pertumbuhan Bivalvia berkisar antara 27-31,3 ppt. Widasari (2013) menambahkan bahwa, rata-rata salinitas berkisar antara 25 - 30 ppt, merupakan nilai yang sesuai dengan habitat kepah. Sebagian besar Bivalvia dapat hidup dengan baik pada kisaran salinitas berkisar antara 5-35 ppt (Rajab et al., 2016).

Tabel 3 merupakan hasil pengolahan substrat didapat berupa lempung, pasir dan lanau. Substrat yang lebih mendominasi 
Jurnal Laut Khatulistiwa, Vol. 3, No. 1 (Febuari, 2020), Hal. 1-9.

Tabel 2. Parameter lingkungan di ekosistem mangrove Desa Peniti selama pengambilan sampel pola distribusi Polymesoda erosa

\begin{tabular}{clcccc}
\hline \multirow{2}{*}{ No. } & \multirow{2}{*}{ Parameter } & \multicolumn{5}{c}{ Stasiun } \\
\cline { 3 - 6 } & & $\mathbf{1}$ & $\mathbf{2}$ & $\mathbf{3}$ & $\mathbf{4}$ \\
\hline 1 & Suhu air $\left({ }^{\circ} \mathrm{C}\right)$ & $26-28,3$ & $26-28$ & $26-28,5$ & $26-28$ \\
2 & pH air & 8,2 & 8,3 & 8,4 & 8,4 \\
3 & Salinitas (ppt) & 27,7 & 25,7 & 27,3 & 28 \\
4 & pH tanah & 6 & 6,3 & 5,3 & 6,3 \\
\hline
\end{tabular}

Tabel 3. Jenis-jenis substrat yang terdapat di ekosistem mangrove Desa Peniti

\begin{tabular}{ccccc} 
No. & Stasiun & $\begin{array}{c}\text { Rata-rata lempung } \\
\mathbf{( \% )}\end{array}$ & $\begin{array}{c}\text { Rata-rata lanau } \\
\mathbf{( \% )}\end{array}$ & $\begin{array}{c}\text { Rata-rata pasir } \\
\mathbf{( \% )}\end{array}$ \\
\hline 1 & & & \\
2 & I & 21,5 & 66,5 & 12 \\
3 & II & 11,5 & 65,5 & 23 \\
4 & III & 20,5 & 56,5 & 23 \\
\hline
\end{tabular}

adalah fraksi lanau atau lumpur (66,5\%), pada stasiun I. Substrat terkecil persentasinya yaitu fraksi lempung $(11,5 \%)$, pada stasiun II. Berdasarkan pengolahan sampel substrat yang didapat jenis substrat pada stasiun I sampai IV berjenis Lanau berpasir. Menurut Dahuri (2004) dalam Siregar et al. (2013) Bivalvia merupakan jenis yang banyak ditemukan pada substrat yang berlumpur. Pendapat ini diperkuat oleh Yunitawati (2012) bahwa jenis dari kelas Bivalvia dapat tumbuh dan berkembang dengan baik pada tipe substrat berlumpur dengan bahan organik tinggi sebagai pakan.

\section{Kesimpulan}

Hasil Berdasarkan hasil penelitian, dapat disimpulkan bahwa penelitian yang telah dilakukan mengenai kepadatan dan pola distribusi Polymesoda erosa di Desa Peniti Kabupaten Mempawah Kalimantan Barat diperoleh kesimpulan bahwa nilai kepadatan Polymesoda erosa yang paling tinggi terdapat pada stasiun II sebesar $0,93 \mathrm{ind} / \mathrm{m}^{2}$. Pola pertumbuhan Polymesoda erosa di Desa Peniti, Kabupaten Mempawah Kalimantan Barat, pada setiap stasiun adalah pola pertumbuhan mengelompok.

\section{Daftar Pustaka}

Amin, R. 2009. Potensi Kerang Kepah (Polymesoda erosa) Perairan Pemangkat Sambas Kalimantan Barat. Tesis. Semarang : Universitas Diponegoro.

Farhan, A. 1998. Studi Laju Pertumbuhan Kerang di Pulau Tarakan Jawa Barat.

Hasibuan, N.A., M.S. Yeanny, dan M. B. Mulya. 2018. Kepadatan Populasi Dan Pola Pertumbuhan Kepah (Polymesoda Erosa) di Pantai Sialang Buah, Kecamatan Teluk Mengkudu, Kabupaten Serdang Bedagai. Skripsi. Sumatra Utara : Universitas Sumatera Utara.

Jongjitvimol, T., K. Boontawon, W. Wattanachaiyingcharoen, dan S. Deowanish. 2005. Nest Dispersion of a Stingless Bee Species, Trigona collina Smith, 1857 (Apidae, Meliponinae) in a Mixed Deciduous Forest in Thailand, The Natural History. Journal of Chulalongkorn University. 5(2):67-71.

Junaidi, E. Effendi dan P. Joko. 2010. Kelimpahan Populasi dan Pola Distribusi Remis (Corbicula sp.) di Sungai Seketak 
Jurnal Laut Khatulistiwa, Vol. 3, No. 1 (Febuari, 2020), Hal. 1-9.

Tembalang Kota. Jurnal Of Management of Aquatic Resources. 1 (1): 1-7.

Kastoro, W. 1988. Beberapa Aspek Biologi Kerang Hijau (Perena viridis L) dari Perairan Binaria, Ancol Teluk Jakarta. Jurnal Penelitian Perikanan Laut. 21-32.

Kelana, P.P., I. Setyobudi, dan M. Kristanti. 2015. Kondisi Habitat Polymesoda erosa Pada Kawasan Ekosistem Mangrove Cagar Alam Leuweng Sancang. Jurnal Akuatik. 6(2): 107-117.

Kresnasari, D., 2010, Analisis Biologi, Sebaran Ukuran Kerang Totok (Polymesoda erosa) di Segara Anakan Cilacap, Semarang. Tesis : Universitas Diponegoro.

Listyaningsih, D.D, E.R. Ardli, dan R.E. Prabowo. 2011. Studi Bioekologi Polymesoda erosa di Ekosistem Mangrove Segara Anakan, Cilacap, Purwokerto. Skripsi : Fakultas Biologi UNSOED.

Listyaningsih, D.D. F. Yulianda, dan Erwin E.R. Ardli. 2013. Kajian Degradasi Ekosistem Mangrove Terhadap Populasi Polymesoda Erosa Di Segara Anakan, CILACAP. Skripsi : Fakultas Biologi UNSOED.

Marwanto, M.R., dan M. S. Awari, S. Rifanjani. 2018. Pengaruh Tekstur, Kandungan Air dan Salinitas Tanah Terhadap Kelimpahan Kerang Kepah (Polymesoda Erosa) di Hutan Mangrove Desa Sungai Bakau Kecil Kabupaten Mempawah. Jurnal Hutan Lestari. 6(1) : 208 - 215.

Morton, B. 1984. A Review of Polymesoda erosa (Geloina) Gray 1842 (Bivalvia: Corbiculidae) from Indo-Pasific Mangrove. Journal Asian Marine Biology. 1: 77-86.

Noor, Y.R, M. Khazali, dan M.N. Suryadiputra. 2006. Panduan Pengenalan Mangrove di Indonesia. Bogor. Wetlands International Indonesia Programe.

Nyabakken, J. W. 1992. Biologi Laut Suatu Pendekatan Ekologi. PT.Gramedia Jakarta. Jakarta.

Odum, E. P. 1994. Dasar - Dasar Ekologi. Gajah Mada University Press.

Poutiers, J.M., Bivalves, In , Carpenter, K.E. and V.H. Niem. 1988, The Living Marine Resources of The Western Central Pacific,
Seaweed, Corals, Bivalves and Gastropods. FAO The UN Roma. (1) : 123 - 358.

Pramudji. 2007. Mangrove in the Coastal Zone Lampung Bay Province of Lampung, A Preliminary Study. Marine Resources Indonesia Journal. 32 (2) :179-184.

Pratami, C.E. 2005. Sebaran Moluska (Bivalvia Dan Gastropoda) Di Perairan Teluk Jobokuto, Pantai Kartini Jepara, Jawa Tengah. Skripsi. Bogor : Institut Pertanian Bogor.

Prisma, 2011, Struktur Komunitas Serasah Mangrove di Kawasan Muara Sungai Peniti, Kabupaten Pontianak. Skripsi. Pontianak : Universitas Tanjungpura.

Romimohtarto, K., S. Juwana. 2009. Ilmu Pengetahuan tentang Biota Laut. Djambatan. Jakarta.

Rudi, E., 1999, Beberapa Aspek Ekologi, Morfologi dan Makanan Kerang Tahu (Meretrix meretrix) di Teluk Miskam, Panimbang, Selat Sunda, Jawa Barat. Tesis. Bogor : Institut Pertanian Bogor.

Simanjuntak. 2009. Hubungan Faktor Lingkungan Kimia, Fisika terhadap Distribusi Plankton di Perairan Belitung Timur, Bangka Belitung. Jurnal Perikanan. 9 (1): 31-45.

Soegianto, A., dan A. Supriyanto. 2008, Concentration of Pathogenic Bacteria and Trace Metals in Bivalve Mollusk (Bivalvia: Arcidae) Harvested from East Java Coast, Indonesia. Jurnal Cah, Biologi Marine. (49) : 201-207.

Suwondo, E., Febrita, dan N. Siregar, 2012, Kepadatan dan Distribusi Bivalvia pada Mangrove di Pantai Cermin Kabupaten Serdang Bedagai Provinsi Sumatra Utara. Jurnal Biogenesis. 9 (1): 45-50.

Wicaksono, C.W. 2002. Studi Beberapa Aspek Reproduksi Keong Macan (Babylonia spirata L.) yang Dipelihara pada Substrat, Suhu dan Salinitas yang Berbeda, Skripsi. Bogor : Institut Pertanian Bogor.

Yunitawati., Sunarto, dan Z. Hasan. 2012. Hubungan antara Karakteristik Substrat dengan Struktur Komunitas Makrozoobenthos di Sungai Cantigi, 
Jurnal Laut Khatulistiwa, Vol. 3, No. 1 (Febuari, 2020), Hal. 1-9.

Kabupaten Indramayu. Jurnal Perikanan dan Kelautan. 3(3): 221227.

Widasari, F.N. 2013. Pengaruh Pemberian Tetraselmis Chuii dan Skeletonema Costatum Terhadap Kandungan EPA dan DHA pada Tingkat Kematangan Gonad Kerang Totok Polymesoda Erosa. Journal of Marine Research. 2(1): 15-24.

Morton, B. 1984. A Review of Polymesoda erosa (Geloina) Gray 1842 (Bivalvia, Corbiculidae) from Indo-Pasific Mangrove, Jurnal Asian Marine Biology. 1: 77-86 